\title{
Combined pulmonary fibrosis and emphysema with rheumatoid arthritis
}

\author{
Naoki Yamamoto 지 , Akihiro Dejima 다, Kenkou Hasatani
}

Department of Internal Medicine, Suzu General Hospital, Suzu, Ishikawa, Japan

\section{Correspondence to} Dr Naoki Yamamoto; ny0724jp@gmail.com

Accepted 25 April 2021

\section{Check for updates}

(C) BMJ Publishing Group Limited 2021. No commercial re-use. See rights and permissions. Published by BMJ.

To cite: Yamamoto N,
Dejima A, Hasatani K. BMJ
Case Rep 2021;14:e243257.
doi:10.1136/bcr-2021-
243257

\section{DESCRIPTION}

A 66-year-old man with rheumatoid arthritis (RA) and chronic obstructive pulmonary disease (COPD) presented to our hospital with exertional dyspnoea. He smoked three packs a day for 34 years until he was diagnosed with RA and COPD at the age of 54 . He still smokes a half pack a day. RA was in remission but had been in high activity until the administration of abatacept at the age of 63. COPD was treated by a long-acting $\beta 2$ agonist and long-acting muscarinic antagonists; however, the modified Medical Research Council dyspnoea scale was grade 3 . On physical examination, we found that he breathed by the shoulder, using accessory muscles. His respiratory sound was lowered in the bilateral upper lungs. However, fine crackles were heard in late inspiration in the bilateral lower lungs. He had club fingers without tenderness and swelling in the joints. Arterial blood gas analysis in room air revealed that arterial oxygen tension and alveolar carbon dioxide tension were $56.0 \mathrm{~mm} \mathrm{Hg}$ and $33.1 \mathrm{~mm} \mathrm{Hg}$, respectively. Chest X-ray radiography revealed bilateral reticular opacities in the lower lungs (figure 1). CT revealed severe emphysema in bilateral upper lobes and interstitial fibrotic changes in bilateral lower lobes (figure 2). However, there was no evidence of lung cancer. The respiratory function test revealed forced expiratory volume in $1 \mathrm{~s}\left(\mathrm{FEV}_{1}\right)$ of $78.3 \%$, forced vital capacity (FVC) of $87.5 \%$ and $\mathrm{FEV}_{1} / \mathrm{FVC}$ ratio of $72.5 \%$. The diffusing capacity of the lung for carbon monoxide $\left(\mathrm{D}_{\mathrm{LCO}}\right)$ was $37.8 \%$. He was diagnosed with combined pulmonary fibrosis and emphysema (CPFE). Ultrasonic echocardiography

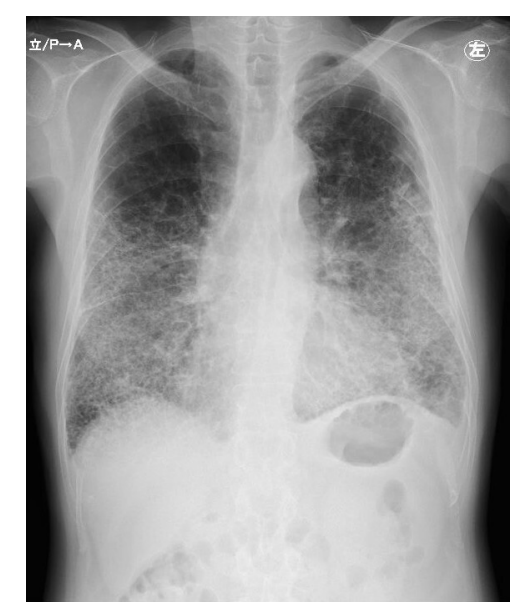

Figure 1 Bilateral reticular opacities in the lower lungs on chest $X$-ray radiography.

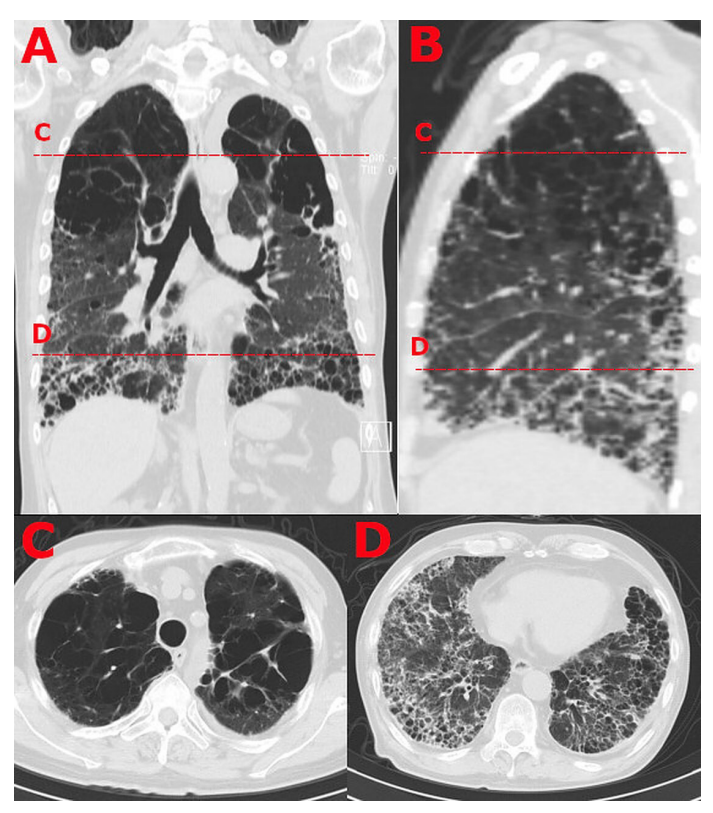

Figure 2 Centrilobular and paraseptal emphysema in the bilateral upper lobes and reticular opacities and honeycombing in the bilateral lower lobes on CT. (A) Bilateral lungs on coronal plane with axial level of section (C, D). (B) Right lungs on sagittal plane with axial level of section (C, D). (C) Bilateral upper lobes on axial plane. (D) Bilateral lower lobes on axial plane.

revealed that estimated right ventricular systolic pressure was within the normal range $(33.8 \mathrm{~mm}$ $\mathrm{Hg}$ ). Home oxygen therapy was initiated in addition to counselling on smoking cessation.

CPFE is characterised by a combination of emphysema of the upper lobes and fibrosis of the lower lobes. Patients with CPFE are mostly men with a current or past smoking habit. Emphysema increases lung compliance, whereas pulmonary fibrosis decreases lung compliance. Therefore, $\mathrm{FVC}$ and $\mathrm{FEV}_{1}$ are counterbalanced in CPFE although chest CT shows evident emphysema and fibrosis. $\mathrm{D}_{\mathrm{LCO}}$ is decreased, reflecting the reduced function of the alveolar-capillary units and alveolar membrane thickening. RA accounts for $53 \%$ of the patients with connective tissue disease (CTD) who also have CPFE. ${ }^{1}$ Compared with idiopathic CPFE, patients with CTD-related CPFE are likely to be younger women with a more favourable prognosis. This may result from earlier recognition of lung disease related to connective tissue disease. ${ }^{12}$ However, CPFE may be associated with a high risk of mortality in RA because $\mathrm{D}_{\mathrm{LCO}}$ is more decreased in RA-related CPFE than 
that of RA-related interstitial lung diseases due to the additional emphysematous change.

This case clearly illustrates the dissociation between radiographic change and preserved lung volume in spirometry. We should, therefore, pay attention to $\mathrm{D}_{\text {LCO }}$ and the association between RA and CPFE.

\section{Learning points}

Forced vital capacity and forced expiratory volume in $1 \mathrm{~s}$ are counterbalanced in combined pulmonary fibrosis and emphysema (CPFE).

- Diffusing capacity of the lung for carbon monoxide is more decreased in rheumatoid arthritis (RA)-related CPFE compared with RA-related interstitial lung diseases.

Contributors NY and AD made substantial contributions to conception and design and have been involved in drafting the manuscript. $\mathrm{KH}$ approved the final version to be published.
Funding The authors have not declared a specific grant for this research from any funding agency in the public, commercial or not-for-profit sectors.

Disclaimer Case reports provide a valuable learning resource for the scientific community and can indicate areas of interest for future research. They should not be used in isolation to guide treatment choices or public health policy.

Competing interests None declared.

Patient consent for publication Obtained.

Provenance and peer review Not commissioned; externally peer reviewed.

\section{ORCID iDs}

Naoki Yamamoto http://orcid.org/0000-0002-4113-0499

Akihiro Dejima http://orcid.org/0000-0002-8422-2406

\section{REFERENCES}

1 Cottin V, Nunes $\mathrm{H}$, Mouthon $\mathrm{L}$, et al. Combined pulmonary fibrosis and emphysema syndrome in connective tissue disease. Arthritis Rheum 2011;63:295-304.

2 Tzouvelekis A, Zacharis G, Oikonomou A, et al. Increased incidence of autoimmune markers in patients with combined pulmonary fibrosis and emphysema. BMC Pulm Med 2013;13:31.

Copyright 2021 BMJ Publishing Group. All rights reserved. For permission to reuse any of this content visit

https://www.bmj.com/company/products-services/rights-and-licensing/permissions/

BMJ Case Report Fellows may re-use this article for personal use and teaching without any further permission.

Become a Fellow of BMJ Case Reports today and you can:

- Submit as many cases as you like

- Enjoy fast sympathetic peer review and rapid publication of accepted articles

- Access all the published articles

Re-use any of the published material for personal use and teaching without further permission

\section{Customer Service}

If you have any further queries about your subscription, please contact our customer services team on +44 (0) 2071111105 or via email at support@bmj.com.

Visit casereports.bmj.com for more articles like this and to become a Fellow 